\title{
Recurrent volcanic activity recorded in araucarian wood from the Lower Cretaceous Springhill Formation, Patagonia, Argentina: Palaeoenvironmental interpretations
}

\author{
Georgina M. Del Fueyo, Martín A. Carrizo, Daniel G. Poiré, and Maiten A. Lafuente Diaz \\ Acta Palaeontologica Polonica 66 (1), 2021: 231-253 doi:https://doi.org/10.4202/app.00783.2020
}

This paper describes a petrified trunk collected from a conglomerate bed of the Springhill Formation (Berriasian-Valanginian) in the Estancia El Álamo locality, Santa Cruz Province, Argentina. The fossil trunk is classified within theubiquitous genus Agathoxylon and the wood anatomy shows a close affinity to that of Araucariaceae. This Patagonianwood has a distinct combination of anatomical characteristics unique among all known species from the Jurassic andCretaceous of Western Gondwana allowing to diagnose a new fossil taxon Agathoxylon mendezii sp. nov. Sedimentologicaland megafloristic proxies of the Springhill Formation suggest that Agathoxylon mendezii sp. nov. grew under awarm and wet climate, which indicates a subtropical to temperate palaeoenvironment. However, the large number of frostrings in the earlywood of this araucarian tree suggests that the palaeoenvironment at Estancia El Álamo was subjected torecurrent disturbances, most likely caused by regional continuous volcanic activity originating from volcanoes locatedfar away to the west. This activity would have produced periodic stratospheric veils that promoted rapid decreases insurface air temperature; the wood response to such stressful conditions would have been the formation of numerous (atleast five) frost rings. Although recurrent eruptions in Patagonia during the Early Cretaceous are well recorded, this studyis the first to register eruptions recorded in a coniferous wood.

Key words: Araucariaceae, Agathoxylon, volcanic eruptions, wood, Berriasian, Valanginian, South America.

Georgina M. Del Fueyo [georgidf@yahoo.com.ar], Martín A. Carrizo [blackdisk@gmail.com ], and Maiten A. Lafuente Diaz [maitenlafuentediaz@gmail.com], Museo Argentino de Ciencias Naturales "Bernardino Rivadavia", CONICET, Av. Ángel Gallardo 470, (1405) Buenos Aires, Argentina. Daniel G. Poiré [poire@ cig.museo.unlp.edu.ar], Centro de Investigaciones Geológicas, UNLP-CONICET, calle 1 n. 644, 1900, La Plata, Buenos Aires, Argentina. 
This is an open-access article distributed under the terms of the Creative Commons

Attribution License (for details please see creativecommons.org), which permits unrestricted use, distribution, and reproduction in any medium, provided the original author and source are credited.

Forif Full text $(9,463.1 \mathrm{kB})$ 